\title{
CONSIDERATIONS OF CRIMINAL LAW AND FORENSIC SCIENCE REGARDING THE ILLEGAL ACCESS TO A COMPUTER SYSTEM
}

\author{
Adrian Cristian MOISE \\ Faculty of Juridical, Economic and Administrative Sciences \\ "Spiru Haret" University of Bucharest, Romania \\ *Correspondence: "Spiru Haret" University of Bucharest,Vasile Conta Street no.4, Craiova, \\ Romania \\ E-mail:adriancristian.moise@ gmail.com
}

A.C. MOISE

\begin{abstract}
Starting from the provisions of Article 2 of the Council of Europe Convention on Cybercrime and from the provisions of Article 3 of Directive 2013/40/EU on attacks against information systems, the present study analyses how these provisions have been transposed into the text of Article 360 of the Romanian Criminal Code. Illegal access to a computer system is a criminal offence that aims to affect the patrimony of individuals or legal entities.

The illegal access to computer systems is accomplished with the help of the social engineering techniques, the best known technique of this kind is the use of phishing threats. Typically, phishing attacks will lead the recipient to a Web page designed to simulate the visual identity of a target organization, and to gather personal information about the user, the victim having knowledge of the attack.
\end{abstract}

KEYWORDS: illegal access; computer system; phishing; attack.

\section{INTRODUCTION}

The offence of illegal access to a computer system is provided by the Article 360 from Chapter VI, entitled Offences against the safety and integrity of computer systems and data from the Romanian Criminal Code. The legal text states:

"(1) Access, without right, to an information system, shall be punishable by imprisonment from 3 months to 3 years or by fine.

(2) The act referred to in paragraph (1), committed in order to get computer data, and shall be punishable by imprisonment from 6 months to 5 years.

(3) Should the act referred to in paragraph (1) was committed in relation to an information system to which, through some procedures, devices or specialised programs, the access is restricted or forbidden for certain categories of users, the punishment is imprisonment from 2 to 7 years".

The offence of illegal access to an information system is stipulated in a simple form, which prohibits the access without right to an information system (paragraph1) and two aggravating variants, consisting in committing the act referred to in paragraph 1 in order to obtain computer data (paragraph 2), as well as in committing the act referred to in paragraph 1 in relation to an information system to which, through some procedures, devices or specialised programs, the access is restricted or forbidden for certain categories of users (paragraph 3).

By access it is understood any successful interaction with an information system, computer or mobile phone, entering the whole or just a part of the computer system ${ }^{1}$. Access without right to an information system means, for the purpose of Article 35 (2) of Law no. $161 / 2003^{2}$ on some measures

\footnotetext{
${ }^{1}$ Spiridon, IonuţCiprian (2008).Reflecţii cu privire la legislaţiaromânăîndomeniulcriminalităţiiinformatice, [Reflections on the Romanian legislation on cybercrime], in Law Review no. 8, p. 243.

${ }^{2}$ The Romanian Official Gazette no. 454 from the $21^{\text {st }}$ of April 2003.
} 


\section{CONSIDERATIONS OF CRIMINAL LAW AND FORENSIC SCIENCE REGARDING THE ILLEGAL ACCESS TO A COMPUTER SYSTEM}

to ensure transparency to exercise public dignities, public office and business environment, prevention and to sanction corruption, that such person is in one of the following situations:

a) is not authorized, under a law or a contract;

b) exceeds the limits of authorization;

c) does not have the permission, from the competent natural or legal person, pursuant to law, to give, use, administer or control an information system or to carry out scientific researches or to carry out any other operation in an information system.

Access means an "interaction of the perpetrator with concerned computer technology, through the equipment or different components of the concerned system" 3 . Thus, the modality of illegal access of information system may be carried out closely, directly by the person in front of the information system, but it may also be carried out from distance, through communication public networks ${ }^{4}$.

\section{CRIMINALIZATION OF THE OFFENCE OF ILLEGAL ACCESS TO A COMPUTER SYSTEM WITHIN THE CONVENTION OF THE COUNCIL OF EUROPE ON CYBERCRIME}

Article 2 of the Council of Europe Convention on Cybercrime ${ }^{5}$ refers to unlawful access, which consists in getting into a computer system, in whole or in part, without right. The offence of illegal access to a computer system is committed by infringement of security measures with the intent of obtaining computer data or with other dishonest intent, or in relation to a computer system that is connected to another computer system. Therefore, this article covers hacking into a computer system ${ }^{6}$. The offence is relatively easy to commit through the Internet, which allows multiple types of connections, from a simple unencrypted connection to a multi-level security connection.

The term access does not specify specific means of communication, but is open to future technical developments ${ }^{7}$. Therefore, this term includes all the means of entry into a computer system, including attacks on the Internet, as well as illegal access to wireless networks ${ }^{8}$. This broad approach demonstrates that illegal access covers not only the subsequent technical developments, but also covers the unauthorized access to computer data by intruders or employees ${ }^{9}$.

As with other offences covered by the Council of Europe Convention on Cybercrime, the Article 2 of the Convention also requires the offender to commit the offence of illegal access with intent. However, we note that the Convention does not define the term withintent. In the

\footnotetext{
${ }^{3}$ Dobrinoiu, Maxim (2006). Infracțiunil̂ndomeniulinformatic, [Crimes in the IT field], Bucharest: C.H. Beck Publishing House, p. 149.

${ }^{4}$ Vasiu, Ioana; Vasiu, Lucian (2011).Criminalitateaîncyberspațiu, [The criminality in cyberspace], Bucharest: UniversulJuridic Publishing House, p. 145.

${ }^{5}$ The European Council Convention on cybercrime was adopted at Budapest $23^{\text {rd }}$ of November 2001. Retrieved $25^{\text {th }}$ of October 2017 from: http://www.conventions.coe.int/Treaty/EN/Treaties/Html/185.htm The European Council Convention on cybercrime was ratified by Romania through the Law no. 64/2004, published in the Romanian Official Gazette no. 343 from the 20 ${ }^{\text {th }}$ of April 2004.

${ }^{6}$ Savin, Andrej (2013).EU Internet Law. Cheltenham, Glos: Edward Elgar Publishing Limited, pp. 236-237.

${ }^{7}$ Gercke, Marco (2009). Council of Europe. Economic Crime Division. Directorate General of HumanRightsand Legal Affairs. Strasbourg, OctopusInterface 2009, Cybercrime training for judges:Training manual(draft), March 2009, p. 27, Retrieved 25 th of October 2017 from:

http://www.coe.int/t/dghl/cooperation/economiccrime/cybercrime/ cy\%20activity\%20interface\%202009/IF 2009_presentations/default_en.asp.

${ }^{8}$ Gercke, Marco (2012).International Telecommunication Union.Understanding Cybercrime: Phenomena, Challenges and Legal Response, p. 179, Retrieved 25 th of October 2017 from: www.itu.int/ITU $\mathrm{D} / \mathrm{cyb} /$ cybersecurity/legislation.html.

${ }^{9}$ Computer Security Institute (2007). CSI Computer Crime and Security Survey 2007, p. 12, Retrieved $25^{\text {th }}$ of October 2017 from: http://gocsi.com/survey.
} 
Explanatory Report to the Council of Europe Convention on Cybercrime, the legislators emphasized that the term with intent should be defined at national level. The illegal access to a computer system to fall under the provisions of the Article 2 of the Council of Europe Convention on Cybercrime must be done without right. The Convention's legislators also underline that testing or protecting the security of a computer system, authorized by an owner, and is done with right.

We believe that the illegal access to a computer systems is in most cases not the end of the illegal act committed by the offender, but rather the first step towards committing additional offences, such as alteration or obtaining stored data.

\section{CRIMINALIZATION OF THE OFFENCE OF ILLEGAL ACCESS TO A COMPUTER SYSTEM WITHIN THE DIRECTIVE 2013/40/EU OF THE EUROPEAN 3. PARLIAMENT AND OF THE COUNCIL OF 12 AUGUST 2013 ON ATTACKS AGAINST INFORMATION SYSTEMS}

The offence stipulated by the Article 3 of the Directive 2013/40/EU ${ }^{10}$ on attacks against information systemsrefers to illegal access to information systems. This category of offences comprises a series of computer attacks, also known in the literature as hacking. The offence consists in committing intentionally the access without right to the whole or to any part of an information system, by infringing a security measure. The offence of illegal access to information systems must not be a minor case. In conformity with ground no. 11 of the Directive 2013/40/EU, a case may be considered minor "where the damage caused by the offence and/or the risk to public or private interests, such as to the integrity of a computer system or to computer data, or to the integrity, rights or other interests of a person, is insignificant or is of such a nature that the imposition of a criminal penalty within the legal threshold or the imposition of criminal liability is not necessary".

The offender in the area of IT illegally accesses a computer system by infringing a security measure. The most commonly encountered security measures used against illegal access to a computer system are the following: passwords, access codes and encryption codes.

\section{ANALYSIS OF THE OFFENCE OF ILLEGAL ACCESS TO A COMPUTER SYSTEM REFERRED TO IN ARTICLE 360 OF THE ROMANIAN CRIMINAL CODE}

\section{III.1. Thepre-existing conditions}

\section{III.1.1. The object of the crime}

The special legal objectof the offence of illegal access to a computer system is the social relations that concern the security of the computer system, its inviolability and which are able to guarantee the confidentiality and integrity of both the computer data and the computer systems ${ }^{11}$.

The material object of the offenceof illegal access to a computer system consists of the components of the computer system on which the criminal activity was directed (such as, for example, the data storage disks) or through which access was made without right (for example, the computer network components).In the case of the variant under paragraph (2),

\footnotetext{
${ }^{10}$ Directive 2013/40/EU of the European Parliament and of the Council of 12 August 2013 on attacks against information systemsand replacing Council Framework Decision 2005/222/JAI, Official Journal of the European Union, 14.08.2013, L218/8.

${ }^{11}$ Romanian Information Technology Initiative; Romanian Government (2004), Ghid introductive pentruaplicareadispozitiilorlegalereferitoare la criminalitateainformatică [An introductory guide to the application of legal provisions on cybercrime], Bucharest, p. 57, Retrieved $25^{\text {th }}$ of October 2017 from: http://www.riti-internews.ro/ro/ghid.htm.
} 


\section{CONSIDERATIONS OF CRIMINAL LAW AND FORENSIC SCIENCE REGARDING THE ILLEGAL ACCESS TO A COMPUTER SYSTEM}

the material object will consist mainly in the material entity on which the computer data is stored and on which the committed activity is directed ${ }^{12}$. Therefore, we consider that this incrimination is intended to protect by criminal means the confidentiality and integrity of the computer systems and the data hosted by them.

\section{III.1.2. The subjects of the crime}

The active subject can be any person who meets the general conditions of the law for criminal liability.

Usually the offender of such an offence is a person who has skills or technical knowledge in the field of information technology, being familiar with the IT security systems and the vulnerabilities of these systems ${ }^{13}$.

Participation is possible in all its forms: co-author, instigation and complicity.

The passive subject of the offence of illegal access to a computer system is the natural or legal person who bears the damage caused by the commission of the offence, this being, as a rule, the owner of the computer system accessed without right or another natural or legal person who is prejudiced by accessing the computer data of interest to the offender.

There may also be one passive secondary subject, where the computer system concerned by the illegal access concerns a natural or legal person other than the owner or the right holder of that computer system ${ }^{14}$. For example, the offender illegally accesses a customer database of a bank by obtaining information about their financial situation or other personal data.

There may also be one collective passive subject, made up of several natural or legal persons, where access to the computer system automatically generates illegal access to other computer systems of the same type interconnected with the first ${ }^{15}$.

\section{The constitutive content}

\section{III.2.1. The objective side}

The material element of the offence of illegal access to a computer system is accomplished by an access activity without right to a computer system.

The illegal access to a computer system can be accomplished through several types of actions: ${ }^{16}$

a. authenticate - present one's identity to a program and, if necessary, verify that identity in order to gain access to the target system;

b. bypass- avoiding a process or program using an alternative method to access the target;

c. read-obtaining the content of a data environment;

d. copy- copying the target without modifying it;

e. steal - taking possession of a target without keeping a copy in the original location.

In order to gain illegal access to a computer system, the cybercriminal will try to use several types of dangerous attacks, such as: the password attack, the free access attack, the attack

\footnotetext{
${ }^{12}$ Vasiu, Ioana; Vasiu, Lucian (2007).Informaticăjuridicăşidreptinformatic, [Legal informatics and IT law], ClujNapoca: “Albastră” Publishing House, p.127.

${ }^{13}$ Vasiu, Ioana; Vasiu, Lucian (2001).Totuldesprehackeri, [Everything about hackers], Bucharest: Nemira Publishing House, p. 151-152.

${ }^{14}$ Dobrinoiu, Maxim (2006). Infracțiuniîndomeniulinformatic, [Crimes in the IT field], Bucharest: C.H. Beck Publishing House, Bucharest, p. 148.

${ }^{15}$ Ibidem.

${ }^{16}$ Romanian Information Technology Initiative; Romanian Government (2004), Ghid introductive pentruaplicareadispozitiilorlegalereferitoare la criminalitateainformatică [An introductory guide to the application of the legal provisions on cybercrime], Bucharest, p. 58, Retrieved $25^{\text {th }}$ of October 2017 from: http://www.riti-internews.ro/ro/ghid.htm.
} 
exploiting technology weaknesses, the attack exploiting shared libraries, the IP hijacking, and the TCP hijacking.

The criminal legislator provides for the aggravating version of the Article 360 paragraph 3 of the Romanian Criminal Code that illegal access is made by using specialized procedures, devices or programs that override security measures, which should restrict or prohibit illegal access for certain users. So, we believe that the cybercriminal will illegally access the computer system by violating these security measures.

Immediate consequence represents the second mandatory component of the objective side and refers to the prejudice of the social value protected by the criminal law, in this situation being the security of the information systems, or a state of danger, or threat created for that value.

There must be a causality link between the activity of the offender and the immediate consequence. In the case of illegal access in a simple form, the causality link results from the materiality of the deed, while for the other two forms of aggravating illegal access in the literature $^{17}$ it was considered that the forcing of security measures had to be proven.

\section{III.2.2. The subjective side}

For the existence of an offence of illegal access to a computer system it is necessary that the offence be committed with guilt. In this situation, the form of guilt necessary is both the direct and indirect intention. In the variant from the paragraph 2 of the Article 360 of the Romanian Criminal Code, the legislator also provides an essential condition for the purpose of achieving illegal access: obtaining computer data.

\section{III.3. The forms of the offence}

The preparatory acts (purchase or manufacture of devices for illegal access) are possible, but they are not criminalized for this crime and as such they are not punishable. However, certain preparatory acts are incriminated as self-contained offences, such as the offence provided by the Article 365 of the Romanian Criminal Code, which refers to illegal operations with computer devices or programs.

The attempt is possible and is punished according to the article 366 of the Romanian Criminal Code.

The consumption of the offence is attained when the access to the attacked computer system has been obtained without right, irrespective of the consequences of the access to the computer system and the data contained therein. The moment of illegal access to the computer system can be determined by specific technical means (for example, with the help of $\log$ files).

The exhaustion of the offence occurs at the time of committing the last act of illegal access to a computer system. The offence can be committed in a continuous form (illegal access existing over a longer period of time) or continued (repeated acts of illegal access to the same computer system and against the same passive subject).

\section{III.4. Modalities}

The offence of illegal access to a computer system presents a normative modality expressed through its material element, by access without right to a computer system. There are several modalities of doing this normative modality.

The offence of illegal access to a computer system also includes two aggravated modalities. The first aggravated modality is when illegal access is made to obtain computer data.

Thus, the cybercriminal acts with qualified direct intention of having a purpose, obtaining computer data, this purpose having to exist at the time of committing the act, being indifferent to the existence of the qualified form, whether the offender succeeds in obtaining such data or not, and whether the data sought by the offender was or not in the illegally accessed computer

\footnotetext{
${ }^{17}$ Hotca, Mihai Adrian; Dobrinoiu, Maxim (2008). Infracţiuniprevăzuteînlegi speciale. Comentariișiexplicații, [Crimes under special laws. Comments and explanations], Bucharest: C.H. Beck Publishing House, p. 581.
} 


\section{CONSIDERATIONS OF CRIMINAL LAW AND FORENSIC SCIENCE REGARDING THE \\ ILLEGAL ACCESS TO A COMPUTER SYSTEM}

system. At the same time, we consider it is indifferent to the existence of the offence in this aggravated modality if the obtained computer data is public or not public, has commercial value or is of a different nature.

The second aggravated modality is when the offence is committed by using specialized procedures, devices or programs that override security measures that should restrict or prohibit illegal access for certain users.

\section{III.5. Sanctions}

The offences provided in the Article 360 of the Romanian Criminal Code are sanctioned as follows:

- the simple form (paragraph 1) shall be punished by imprisonment from 3 months to 3 years or by fine;

- the first aggravating form (paragraph 2) shall be punished by imprisonment from 6 months to 5 years;

- the second aggravating form (paragraph 3) shall be punished by imprisonment from 2 to 7 years.

\section{III.6. Procedural Aspects}

The criminal prosecution begins ex officio.

\section{FREQUENTLY USED TECHNIQUES BY CYBERCRIMINALS FOR THE PURPOSE OF ILLEGAL ACCESS TO COMPUTER SYSTEMS AND NETWORKS}

\section{IV.1.Phishing}

Phishing represents a practice of sending fake e-mails, or spam, written to appear as if they had been sent by banks or other respectable organizations, with the intention to lure the recipient into disclosing important information, such as usernames, passwords, account IDs, PIN codes of some credit cards ${ }^{18}$. Typically, phishing attacks will lead the recipient to a Web page designed to simulate the visual identity of a target organization, and to gather personal information about the user, the victim having knowledge of the attack.

Obtaining this type of personal data is attractive to criminals, because it allows attackers to impersonate their victims and to make fraudulent financial transactions. Victims often suffer significant financial losses or their whole identity is stolen, usually for criminal purposes.

Over time, the definition of what constitutes a phishing attack has become blurred and expanded.

The term phishing covers not only getting the user account details, but it now covers access to all personal and financial data ${ }^{19}$.

What originally prompted deceiving users to answer e-mails for passwords and credit card details, it has now has extended to false Web sites, installing Trojan horses, key-logger and screen capture, which are all delivered by any electronic communication channels. Given the success of this type of crime, an extension of the classic phishing fraud includes the use of fake Web sites about workplaces or job offers.

The first step of this mode of operation is the creation of fake websites that imitate the pages of known financial institutions such as banks or retailers conducting online transactions with the use of credit cards. Once created, these fake sites are hosted by Internet service providers.

\footnotetext{
${ }^{18}$ The Honeynet Project.Know Your Enemy: Phishing, Retrieved 25 $5^{\text {th }}$ of October 2017 from: http://www.honeynet.org/papers/ phishing.

${ }^{19}$ Ollmann, Gunter. Next Generation Security Software Ltd., NGSSoftware Insight Security Research, The Phishing Guide. Understanding \&Preventing Phishing Attacks, p. 4, Retrieved $25^{\text {th }}$ of October 2017 from: http://www.ngssoftware.com/papers/ NISR-WP-PHISHING.PDF.
} 
Hosting can also be realized with no authorization on certain servers, or by paying for this service fraudulently, with electronic payment means.

The next step is to obtain the e-mail addresses of the clients of these financial institutions, which is realized by certain specialized programs, or through unauthorized access to databases containing this information.

After obtaining the customers' e-mail addresses, they are sent messages as if these messages came from the real financial institution whose website has been forged, by asking customers to enter their credit card data (credit card number, expiry date and PIN code), by giving various excuses.

Regarding the legal status of phishing, it should be noted that phishing is not specifically criminalized in the Romanian legislation. If the offender commits the act by spoofing ${ }^{20}$, by simulating e-mail or by rewriting the URL, the act constitutes the crime of computer-related forgery, which is provided by the article 325 of the Romanian Criminal Code.

Phishing can also fall within the crime of deceit under the article 244 of the Romanian Criminal Code, when the act of sending messages in order to obtain the identification data of an account or a person produces a loss.Moreover, from our point of view, phishing could be criminalized by the article 249 of the Romanian Criminal Code, which refers to the crime of computer-related fraud.

\section{IV.2. Phishing threats}

Phishing attacks are based on a combination of technical deceit and social engineering practices. In most cases, the attacker must persuade the victim to deliberately perform a series of actions that will give the attacker access to confidential information ${ }^{21}$.

Communication channels such as e-mail, web pages, IRC (Internet Relay Chat) and instant messaging services are used by the majority of the population. In all cases, the attacker has to play the role of a trustworthy source so that the victim believes it. The most successful phishing attack was initiated via e-mail, where the attacker plays the role of the referral authority (e.g., spoofing the source e-mail address).

\section{IV.2.1. Distribution of phishing messages based on e-mail and spam}

E-mail-based phishing attacks are the most common. Using techniques and tools used by spam, attackers can distribute misleading emails to millions of legitimate email addresses in just a few hours. In many cases, address lists used to distribute phishing e-mails are purchased from the same sources used by conventional spam.

Examples of techniques used in phishing emails: ${ }^{22}$

a. Searching for and officially probing emails.

b. Copying corporate emails with minor URL (Uniform Resource Locator) changes.

c. E-mails sent in HTML format used to cover the information of target URL address.

d. Viruses and worms attachments to e-mails.

e. Including spam detection techniques.

\section{IV.2.2. Web-based phishing distribution messages}

An increasingly popular method of phishing attacks is the malicious content of websites. Examples of web-based phishing spamming techniques: ${ }^{23}$

a. websites.

\footnotetext{
${ }^{20}$ The term spoofing refers to the act of presenting that the computer data come from another source than the original one, by hiding from the addressee the true origin of data.

${ }^{21}$ Ollmann, Gunter. Next Generation Security Software Ltd., NGSSoftware Insight Security Research, The Phishing Guide. Understanding \&Preventing Phishing Attacks, p. 5, Retrieved 25 th of October 2017 from: http://www.ngssoftware.com/papers/ NISR-WP-PHISHING.PDF.

${ }^{22}$ Idem, p. 6.

${ }^{23}$ Idem, p.7.
} 
b. $\quad$ Use of counterfeit advertising messages to lure buyers.

c. Use Web-bugs to track a potential client in order to prepare for a phishing attack.

d. Introducing a malicious content into a webpage that exploits a known vulnerability in the customer's web browser software and installing by the attacker of a software (for example, Keylogger, Backdoor, Trojan horses, etc.)

e. The abuse of trust relationships concerning the configuration of the customer's web browser for the use of authorized components that use site scripts.

\section{CONCLUSIONS}

Illegal access to an information system is a means-offence which is aimed at affecting the patrimony of natural or legal persons ${ }^{24}$. We consider that Romanian legislators should modify both the title and the content of the Article 360 of the Romanian Criminal Code (illegal access to an information system), as from the technical point of view illegal access is carried out within an information system, notto an information system.

We noticed that the provisions of the Article 2 (illegal access) of the Council of Europe Convention on cybercrime, as well as the provisions of the Article 3 (illegal access to information systems) of the Directive 2013/40/EU on attacks against information systems were transposed in the Article 360 of the Romanian Criminal Code.

Finally, we believe phishing is the creation of messages sent by e-mails and webpages that are accurate reproductions of existing sites to mislead users to disclose personal and financial data, or passwords. Therefore, phishing e-mails appear to be sent from a bank, an insurance company, a trader or an electronic payment processor.

\section{REFERENCES}

1. Computer Security Institute (2007). CSI Computer Crime and Security Survey 2007, Retrieved $25^{\text {th }}$ of October 2017 from: http://gocsi.com/survey.

2. Dobrinoiu, Maxim (2006). Infracțiuniîndomeniulinformatic, [Crimes in the IT field], Bucharest: C.H. Beck Publishing House.

3. Gercke, Marco (2009). Council of Europe. Economic Crime Division. Directorate General of Human Rights and Legal Affairs. Strasbourg, Octopus Interface 2009, Cybercrime training for judges:Training manual(draft), March 2009.

4. Gercke, Marco (2012). International Telecommunication Union. Understanding Cybercrime: Phenomena, Challenges and Legal Response. Geneva.

5. The Honeynet Project.Know Your Enemy: Phishing, Retrieved $25^{\text {th }}$ of October 2017 from: http://www.honeynet.org/papers/ phishing.

6. Hotca, Mihai Adrian; Dobrinoiu, Maxim (2008). Infracţiuniprevăzuteînlegispeciale. Comentariișiexplicații, [Crimes under special laws. Comments and explanations], Bucharest: C.H. Beck Publishing House.

7. Ollmann, Gunter. Next Generation Security Software Ltd., NGSSoftware Insight Security Research, The Phishing Guide. Understanding \& Preventing Phishing Attacks.

8. Reed, Chris; Angel, John (2007). Computer Law. The Law and Regulation of Information Technology. Sixth Edition. Oxford: Oxford University Press.

9. Romanian Information Technology Initiative; Romanian Government (2004), Ghid introductive pentruaplicareadispoziţiilorlegalereferitoare la criminalitateainformatică [An introductory guide to the application of legal provisions on cybercrime], Bucharest, Retrieved $25^{\text {th }}$ of October 2017 from: http://www.riti-internews.ro/ro/ghid.htm.

\footnotetext{
${ }^{24}$ Reed, Chris; Angel, John (2007).Computer Law. The Law andRegulation of Information Technology. SixthEdition. Oxford: Oxford University Press, pp. 565-567.
} 
10. Spiridon, IonuţCiprian (2008).Reflecţii cu privire la legislaţiaromânăîndomeniulcriminalitătiiiinformatice, [Reflections on the Romanian legislation on cybercrime], in Law Review no. 8.

11. Savin, Andrej (2013). EU Internet Law. Cheltenham, Glos: Edward Elgar Publishing Limited.

12. Vasiu, Ioana; Vasiu, Lucian (2001). Totuldesprehackeri, [Everything about hackers], Bucharest: Nemira Publishing House.

13. Vasiu, Ioana; Vasiu, Lucian (2007). Informaticăjuridicăşidreptinformatic, [Legal informatics and IT law], Cluj-Napoca: Albastră Publishing House.

14. Vasiu, Ioana; Vasiu, Lucian (2011). Criminalitateaîncyberspațiu, [The criminality in cyberspace], Bucharest: UniversulJuridic Publishing House.

15. Directive 2013/40/EU of the European Parliament and of the Council of 12 August 2013 on attacks against information systemsand replacing Council Framework Decision 2005/222/JAI, Official Journal of the European Union, 14.08.2013, L218/8.

16. The European Council Convention on cybercrime. 